TeOlogia I Moralność

Volumen 11(2016), numer 2(20)

doi: 10.14746/TIM.2016.20.2.6

JANUSZ GREZŹLIKOWSKI

Uniwersytet Kardynała Stefana Wyszyńskiego w Warszawie

Wydział Prawa Kanonicznego

\title{
Reforma procesu w sprawie orzekania nieważności małżeństwa elementem nowej ewangelizacji
}

A Reform of the Process on the Assessment of Nullity of Marriage as an Element of New Evangelization

Kiedy mówimy o nowej ewangelizacji, zdajemy sobie sprawę, iż podejmujemy trudne i złożone zagadnienie związane z troską o przekaz wiary z nowym dynamizmem i za pomocą nowych środków, które będą adekwatne dla współczesnego świata i mentalności współczesnego człowieka. Tematyka ta odnosi się również do małżeństwa i rodziny, które są bezpośrednio zaangażowane w dzieło nowej ewangelizacji i od których wiele zależy, gdyż są podstawowym podmiotem i przedmiotem ewangelizacji. W zwierciadle rodziny i małżeństwa Kościół bowiem dostrzega obraz relacji, jaką on sam winien nawiązywać ze światem, aby głosić mu Dobrą Nowinę. Widać to bardzo wyraźnie w nauczaniu papieża Franciszka. Za jego pontyfikatu nowa ewangelizacja nabiera większej mocy i nowego ducha. Stałym i wielokrotnie powtarzanym przesłaniem papieskim jest nieustanny apel o Kościół otwarty, dynamiczny, wychodzący ku ludziom zagubionym i potrzebującym. Papież naucza o potrzebie „wychodzenia do ludzi”, o konieczności podejmowania dialogu z tymi, którzy opuszczają Kościół, wskazuje na potrzebę „,nawrócenia duszpasterstwa”, które nie może być „odległe”, pozbawione bliskości, czułości i serdeczności. Nowa ewangelizacja to więc troska o działania zmierzające do tego, aby Kościół „rozgrzewał serca” ludzi, a nie „konserwował” wiary, lecz ją nieustannie pomnażał. Ma to mieć również przełożenie na wymiar prawny i prawno-duszpasterski działalności Kościoła i jego instytucji, które winny dążyć do tego, aby przekazywały łaskę Bożą, stale sprzyjały dobru wiernych oraz kierowały się zawsze najwyższym dobrem, jakim jest zbawienie dusz ${ }^{1}$.

\footnotetext{
${ }^{1}$ Kan. 1752 KPK.
} 
Ważnym elementem o charakterze prawnym i prawno-duszpasterskim w odniesieniu do małżeństwa i rodziny w perspektywie nowej ewangelizacji jest przeprowadzona przez papieża Franciszka reforma kanonicznego procesu w sprawie orzekania nieważności małżeństwa. Otóż, w nawiązaniu do ogłoszonego bullą Misericordiae vultus (Oblicze miłosierdzia) Jubileuszowego Roku Miłosierdzia, który był obchodzony w Kościele od 8 grudnia 2015 r. do 20 listopada 2016 r. i był szczególnym czasem łaski, umocnieniem świadectwa wiary wiernych i ,zatopienia" ich w źródle tajemnicy Bożego Miłosierdzia², papież Franciszek, wpisując się w treści duchowe i religijne nowej ewangelizacji, Roku Jubileuszowego oraz kierując się najwyższym prawem, jakim jest prowadzenie wiernych do zbawienia (salus animarum) ${ }^{3}$, podjął się dzieła zreformowania kanonicznego procesu o nieważności małżeństwa. W tym celu powołał 27 sierpnia 2014 r. komisję złożoną z wybitnych specjalistów w zakresie nauki prawa kanonicznego, obdarzonych roztropnością duszpasterską i doświadczeniem w praktyce sądowej, na czele której stanął Dziekan Roty Rzymskiej, a której celem było przygotowanie i opracowanie projektu reformy, z pełnym poszanowaniem zasady nierozerwalności węzła małżeńskiego. Po sprawnych pracach komisji nad rewizją postępowania procesowego i konsultacjach z ekspertami, papież Franciszek 15 sierpnia 2015 r., listem apostolskim motu proprio Mitis Iudex Dominus Iesus, reformującym kanony Kodeksu prawa kanonicznego, dotyczące spraw o orzeczenie nieważności oraz listem apostolskim motu proprio Mitis et misericors Iesus, reformującym kanony Kodeksu kanonów kościołów wschodnich, ogłosił nowe normy regulujące prowadzenie kanonicznego procesu o nieważność małżeństwa ${ }^{4}$. Dokument ten wszedł w życie 8 grudnia 2015 r. Wejście w życie zreformowanego prawa $\mathrm{w}$ zakresie procesu o orzeczenie nieważności małżeństwa zbiegło się zatem z rozpoczęciem Jubileuszowego Roku Miłosierdzia, co jest symptomatyczne, gdyż uświadamia i przybliża ważność oraz znaczenie wykonywania posługi sprawiedliwości w Kościele, a tym samym wpisuje się w dzieło nowej ewangelizacji. Podjęta reforma ma służyć ochronie godności małżeństwa, sprawnemu dochodzeniu podmiotowych uprawnień wiernych, a tym bardziej zbawieniu dusz, które niezmiennie pozostaje najwyższym celem procesowego prawa małżeńskiego oraz osób zaangażowanych w wymierzanie sprawiedliwości w Kościele 5 .

\footnotetext{
${ }^{2}$ Papież Franciszek, bulla ustanawiająca nadzwyczajny Jubileusz Miłosierdzia Misericordiae vultus (11.04.2015), „Miesięcznik Diecezji Włocławskiej - Kronika” 98(2015), nr 5, s. 499-500.

${ }^{3}$ Por. kan. 1752 KPK.

${ }^{4}$ Papież Franciszek, list apostolski motu proprio Mitis Iudex Dominus Iesus, reformujący kanony Kodeksu prawa kanonicznego, dotyczące spraw o orzeczenie nieważności małżeństwa; list apostolski motu proprio Mitis et misericors Iesus, reformujący kanony Kodeksu kanonów kościołów wschodnich, dotyczące spraw o orzeczenie nieważności małżeństwa (tekst łacińsko-polski), Tarnów 2015.

5 Tamże, s. 9-11.
} 
Swoimi nowymi regulacjami i rozwiązaniami Mitis Iudex Dominus Iesus wzbudza żywe zainteresowanie, a nawet rozbieżne opinie. Celem zmian wprowadzonych do kanonicznego procesu małżeńskiego nie jest - jak to sugeruja media świeckie - ułatwienie uzyskania orzeczenia nieważności małżeństwa, ale przede wszystkim przyspieszenie prowadzenia procesów kościelnych o nieważność małżeństwa, jak też uproszczenie niektórych procedur kanonicznych ${ }^{6}$. Chodzi o to, jak napisał papież Franciszek, by przyspieszyć procesy stwierdzenia nieważności małżeństwa, tak, aby szybciej służyć wiernym, którzy znaleźli się w takich sytuacjach i z powodu opóźnienia wydania sądowego orzeczenia czekający na nie wierni nie byli „gnębieni przez mroki wątpliwości”, ale „skorzystali z posługi i miłosierdzia, z jaką wychodzi do nich Kościół, dając możliwość zawarcia nowego małżeństwa kanonicznego, jeżeli okaże się to możliwe ${ }^{8}$. Zasady przy tej zmianie są jasne i oczywiste, prowadzenie procesu stwierdzenia nieważności małżeństwa ma zostać w niektórych oczywistych dowodowo sytuacjach przyspieszone, jednakże musi się dokonywać z całkowitym poszanowaniem natury małżeństwa, którym jest poszanowanie prawdy.

Jak zatem wyglądają w świetle papieskiego dokumentu nowe przepisy kanonicznego procesu o nieważność małżeństwa, jakie nowe rozwiązania prawne i proceduralne proponuje i wprowadza papież Franciszek? Na czym polega nowy sposób zagwarantowania właściwego funkcjonowania sprawiedliwości w Kościele, a przede wszystkim orzekania nieważności małżeństwa przy poszanowaniu zasady nierozerwalności małżeństwa, zachowaniu jedności w wierze i w dyscyplinie dotyczącej małżeństwa?

\section{Z HISTORII KANONICZNEGO PROCESU MAŁŻEŃSKIEGO}

Kanoniczny proces o stwierdzenie nieważności małżeństwa ma swoją ciekawą i bogatą historię. Przez wiele wieków sprawy o nieważność małżeństwa były rozpatrywane według ogólnych zasad procesowych. Wskutek wzrostu liczby wnoszonych spraw, proces małżeński zaczął przybierać w dużej mierze formy procesu rzymskiego, przyjmując formy określone przez ustawodawstwo soborowe i synodalne. Kiedy zaś nadmiar przepisów proceduralnych powodował przedłużanie się $\mathrm{w}$ dochodzeniu do rozstrzygania spraw, został wprowadzony przez papieża Klemensa V w 1306 r. konstytucją Saepe contingit proces skrócony ${ }^{9}$. Ten sam Papież sprawy małżeńskie nakazał prowadzić w trybie postępowa-

\footnotetext{
${ }^{6}$ P.V. Pinto, Reforma procesu w sprawie orzekania nieważności matżeństwa, „L’Osservatore Romano" (ed. polska), 36(2015), nr 11, s. 44.

${ }^{7}$ Papież Franciszek, list apostolski motu proprio Mitis Iudex Dominus Jesus..., s. 9.

${ }^{8}$ P.V. Pinto, Reforma procesu w sprawie orzekania nieważności matżeństwa..., s. 44.

${ }^{9}$ C.2, V,11 in Clem.
} 
nia uproszczonego ${ }^{10}$. Reformę norm prawnych w przedmiocie procesu małżeńskiego przeprowadził następnie Sobór Trydencki (1545-1563) ${ }^{11}$, zaś papież Benedykt XIV konstytucją apostolską Dei miseratione z $1741 \mathrm{r}$. dokonał rozbudowania i wyodrębnienia procesu małżeńskiego z ogólnego procesu sądowego, ujednolicając system papieskiej łaski rozwiązania węzła małżeństwa zawartego i niedopełnionego, jak też wprowadzając zasadę dwuinstancyjności w orzekaniu spraw o nieważność małżeństwa ${ }^{12}$. System ten obowiązywał aż do naszych czasów, a instytucja kanonicznego procesu małżeńskiego utrwalała się poprzez liczne instrukcje wydawane przez Stolicę Apostolską ${ }^{13}$.

Ważnym etapem w rozwoju sądownictwa kościelnego, w tym kanonicznego procesu małżeńskiego, było wydanie 29 czerwca 1908 r. przez papieża Piusa X konstytucji apostolskiej Sapienti consilio ${ }^{14}$, która odrodziła i zaakcentowała znaczenie i rolę trybunałów Stolicy Apostolskiej - Roty Rzymskiej i Sygnatury Apostolskiej. Tej pierwszej dokument przypisał do jej właściwości sprawy małżeńskie, pozostawiając niektóre w gestii Kongregacji Sakramentów. Ponadto Papież dokonał wspomnianym dokumentem oddzielenia władzy sądowej od władzy administracyjnej ${ }^{15}$.

Normy odnośnie procesu małżeńskiego znalazły się również w Kodeksie prawa kanonicznego z 1917 r., regulował je osobny tytuł ${ }^{16}$. Jednakże w procesie małżeńskim, obok przepisów specjalnych, obowiązywały zasady zwyczajnego procesu spornego ${ }^{17}$. Wymagało to wydania przez Stolicę Apostolską wielu szczegółowych instrukcji, spośród których najważniejszą z punktu widzenia praktyki sądowej była instrukcja wydana przez Kongregację Sakramentów Provida Mater Ecclesiae z 15 sierpnia $1936 \mathrm{r}^{18}$ Była ona autorytatywnym przewodnikiem i szczegółowym komentarzem dla trybunałów diecezjalnych, rozpatrujących sprawy o nieważność małżeństwa.

Podczas obrad II Soboru Watykańskiego (1962-1965) wielu biskupów postulowało zreformowanie procedury $\mathrm{w}$ sprawach małżeńskich. Wynikało to $\mathrm{z}$ faktu,

\footnotetext{
${ }^{10}$ C.2, II, 1 in Clem.

${ }^{11}$ Conc. Trid., sess. XIII, c. 20 de ref.; sess. XXIV, c. 20 de ref.; sess. XXV, c. 10 de ref.

${ }^{12}$ Benedictus XIV, Constitutio Dei miseratione (03.11.1741), w: Codicis Iuris Canonici Fontes, t. I, ed. P. Gasparri, Romae 1923, s. 695-701.

${ }^{13}$ W. Góralski, Wprowadzenie do motu proprio „Mitis Iudex Dominus Iesus”, w: Proces malżeński wedlug motu proprio Mitis Iudex Dominus Jesus, red. J. Krajczyński, Płock 2015, s. 10.

${ }^{14}$ Pius X, Constitutio apostolica Sapienti Consilio (29.06.1908), "Acta Apostolicae Sedis" (dalej: AAS) 1(1909), s. 9-135.

${ }_{15}$ T. Pawluk, Prawo kanoniczne wedtug Kodeksu Jana Pawła II, t. IV: Dobra doczesne Kościoła, Sankcje w Kościele, Procesy, Olsztyn 1990, s. 314.

${ }^{16}$ Zob. kan. 1960-1992 KPK z 1917 r.

${ }^{17}$ T. Pawluk, Prawo kanoniczne wedlug Kodeksu Jana Pawła II..., t. IV, s. 314.

${ }^{18} \mathrm{~S}$. Congregatio pro Sacramentis, Instructio servanda a tribunalibus dioecesanis in pertractandis causis de nullitatae matrimoniorum (15.08.1936), AAS 28(1936), s. 313-362.
} 
że wobec zwiększającej się liczby spraw małżeńskich, wnoszonych do sądów kościelnych, rozbudowane przepisy kanonicznego prawa procesowego nie pozwalały na sprawne prowadzenie procesów o orzeczenie nieważności małżeństwa. Stąd powołana w 1963 r. Papieska Komisja do Rewizji Kodeksu Prawa Kanonicznego, wspierana przez konsulatorów, zaczęła debatować nad reformą i usprawnieniem kanonicznego procesu małżeńskiego ${ }^{19}$. W ramach posoborowej odnowy prawa kanonicznego, 15 sierpnia 1967 r. papież Paweł VI wydał konstytucję apostolską Regimini Ecclesiae universae, mocą której nadzór nad trybunałami kościelnymi przeniósł z Kongregacji Sakramentów do Sygnatury Apostolskiej. Konstytucja ustaliła także ogólne zasady dotyczące spraw małżeńskich $\mathrm{w}$ dykasteriach rzymskich ${ }^{20}$. Postulat zreformowania procesu małżeńskiego, a szczególnie jego uproszczenia i przyspieszenia, zgłoszono również podczas obrad synodu biskupów w 1970 r., a także postulowali w tej sprawie liczni przedstawiciele doktryny ${ }^{21}$. Nadto liczne konferencje biskupów (Stanów Zjednoczonych, Kanady, Australii, Belgii, Anglii, Francji) zwracały się o specjalne indulty $\mathrm{w}$ sprawach małżeńskich, a dotyczące uproszczenia procedury $\mathrm{w}$ sprawach o stwierdzenie nieważności małżeństwa ${ }^{22}$.

Rezultatem tych postulatów i próśb była sugestia zaproponowana przez Papieską Komisję do Rewizji Kodeksu Prawa Kanonicznego papieżowi Pawłowi VI, aby dokonał zmian w prawie procesowym w odniesieniu do spraw o nieważność małżeństwa jeszcze przed promulgacją nowego Kodeksu. Przychylając się do tej sugestii, Ojciec Święty wydał 28 marca 1971 r. motu proprio Causas matrimoniales, dzięki któremu zostało nieco uproszczone postępowanie w sprawach małżeńskich i tym samym stworzono warunki do sprawniejszego rozpatrywania tych spraw $^{23}$. Zmiany dokonane przez powyższy dokument dotyczyły przede wszystkim: rozszerzenia właściwości sądu, możliwości rozpoznania sprawy przez jednego sędziego, jak też włączenia mężczyzny świeckiego do kolegium sędziowskiego oraz dopuszczenia do funkcji audytora, asesora oraz notariusza osób

${ }^{19}$ T. Pawluk, Prawo kanoniczne wedtug Kodeksu Jana Pawła II..., t. IV, s. 314.

${ }^{20}$ Paulus VI, Constitutio apostolica Regimini Ecclesiae universae (15.08.1967), AAS 59 (1967), s. 885-928; por. W. Góralski, Wprowadzenie do motu proprio Mitis Iudex Dominus Iesus..., s. 11.

${ }^{21}$ Zob. A. Przybyła, Prawo kanoniczne w świetle obrad Synodu Biskupów, „Ateneum Kapłańskie" 71(1968), s. 161-162.

${ }^{22}$ W. Góralski, Uprawnienia udzielone trybunałom kościelnym Belgii oraz Anglii i Walii w zakresie procesu matżeńskiego, „Prawo Kanoniczne” 17(1974), nr 3-4, s. 107-115; T. Pieronek, Normy postępowania $w$ sprawach matżeńskich wydane przez Stolice Apostolskq dla diecezji Stanów Zjednoczonych, „Prawo Kanoniczne” 16(1973), nr 1-2, s. 177-204; por. T. Pawluk, Reforma kanonicznego procesu matżeńskiego w świetle motu proprio Causas matrimoniales, „Prawo Kanoniczne" 16 (1973), nr 3-4, s. 247-248.

${ }^{23}$ Paulus VI, Litterae apostolacie motu proprio datae quibus normae quaedam statuuntur ad processus matrimoniales expeditus absolvendos (28.03.1971), AAS 63(1971), s. 441-446. 
świeckich, uproszczenia procedury $\mathrm{w}$ drugiej instancji, gdy w pierwszej zapadł wyrok pro nullitate, a także w trzeciej instancji, gdy wniesiono rekurs przeciwko dekretowi drugiej instancji, zatwierdzającemu wyrok pierwszej instancji, określenia zasady dotyczącej dopuszczalności prowadzenia procesu skróconego w ściśle określonych przypadkach (istnienie przeszkody zrywającej, możliwej do udowodnienia pewnym i autentycznym dokumentem, niezachowanie formy kanonicznej oraz nieważności pełnomocnictwa ${ }^{24}$.

Posoborową reformę procesu małżeńskiego, rozpoczętą przez Pawła VI, dokończył Jan Paweł II w promulgowanym przez siebie 25 stycznia 1983 r. Kodeksie prawa kanonicznego. Proces o orzeczenie nieważności małżeństwa został uregulowany w kan.1671-1691, a także w odpowiednich przepisach zwyczajnego procesu spornego, do których odsyłał kan. $1691^{25}$. Normy te zostały następnie uzupełnione instrukcją Dignitas connubii z 25 stycznia 2005 r. ${ }^{26}$

Po zwołaniu przez papieża Franciszka Nadzwyczajnego Zgromadzenia Synodu Biskupów w 2014 r., jeszcze przed rozpoczęciem jego obrad, Ojciec Święty powołał 27 sierpnia tegoż roku specjalną komisję, złożoną z wybitnych znawców prawa kanonicznego i teologii pastoralnej, mających jednocześnie doświadczenie sądowe, na czele której stał Dziekan Roty Rzymskiej, aby przygotowała projekt reformy procesu małżeńskiego, $\mathrm{z}$,,pełnym poszanowaniem - jak to zaznaczył Papież - zasady nierozerwalności węzła małżeńskiego"27. Po trudnych i wnikliwych, ale sprawnych pracach komisji nad rewizją postępowania procesowego i konsultacjach $\mathrm{z}$ ekspertami, a także uwzględniając postulaty wysunięte przez większość biskupów podczas synodu biskupów z października 2014 r., papież Franciszek 15 sierpnia 2015 r., listem apostolskim motu proprio Mitis Iudex Dominus Iesus, reformującym kanony Kodeksu prawa kanonicznego, dotyczące spraw o orzeczenie nieważności, ogłosił nowe normy regulujące prowadzenie kanonicznego procesu o nieważność małżeństwa ${ }^{28}$.

Dokument ten, promulgowany 8 września 2015 r., wszedł w życie 8 grudnia tegoż roku i ma na względzie nie tylko zagwarantowanie właściwego funkcjonowania sprawiedliwości w Kościele, ale przede wszystkim wychodzi naprzeciw potrzebie uproszczenia procedury orzekania nieważności małżeństwa, przy zagwarantowaniu ochrony jedności w wierze i dyscyplinie dotyczącej małżeń-

${ }^{24}$ Zob. T. Pawluk, Reforma kanonicznego procesu matzeńskiego w świetle motu proprio Causas matrimoniales..., s. 251-283.

${ }^{25}$ Kann. 1671-1691; Zob. T. Pawluk, Prawo kanoniczne wedtug Kodeksu Jana Pawta II..., t. IV, s. 315.

${ }^{26}$ Pontificium Consilium de Legum Textibus, Instructio servanda a tribunalibus dioecesanis et interdioecesanis in pertractandis causis nullitatis matrimonii Dignitas connubii, Libreria Editrice Vaticana 2005; tekst polski dokumentu w j. łacińskim i w j. polskim zawiera Komentarz do Instrukcji procesowej „Dignitas connubii”, red. T. Rozkrut, Sandomierz 2007.

${ }^{27}$ Papież Franciszek, list apostolski motu proprio Mitis Iudex Dominus Iesus..., s. 7-9.

${ }^{28}$ Tamże. 
stwa $^{29}$. Motu proprio składa się z trzech elementów redakcyjnych: 1. część wstępna wskazująca na genezę, motywy i cele reformy; 2. niektóre podstawowe założenia reformy; 3. dyspozycje modyfikujące przepisy rozdziału „Sprawy o stwierdzenie nieważności małżeństwa" (kan. 1671-1691 KPK). Do motu proprio dołączono „Zasady proceduralne w sprawach o stwierdzenie nieważności”, uznane przez ustawodawcę za obowiązujące ${ }^{30}$. Jak sugeruje ks. prof. W. Góralski, zostały one „opracowane najprawdopodobniej przez wspomniany zespół ekspertów, kierowany przez Dziekana Roty Rzymskiej i nie mają na celu przedstawiania całego procesu w szczegółach, lecz przede wszystkim wyjaśnienie podstawowych nowości legislacyjnych i ich uzupełnienie tam, gdzie jest to konieczne"31.

Przeprowadzona reforma skutkuje uchyleniem lub zmodyfikowaniem dotychczasowych norm prawnych (kan. 1671-1691) obowiązującego Kodeksu prawa kanonicznego oraz wprowadzeniem nowych regulacji w tym zakresie. Ich celem jest przede wszystkim dobro duchowe, a w szczególności zbawienie małżonków związanych kanonicznym węzłem małżeńskim, którzy rozwiedli się i żyją w nowych (tzw. nieregularnych) związkach, i którzy pragną uregulować swój status cywilny na forum kościelnym albo już złożyli w sądzie kościelnym odpowiedni w tym celu wniosek ${ }^{32}$.

\section{OCHRONA NIEROZERWALNOŚCI MAŁŻEŃSTWA ORAZ ZBAWIENIE WIERNYCH NACZELNĄ ZASADĄ REFORMY}

Dwie zasady stanowią niejako fundament reformy oraz najwyższe prawo, a mianowicie: ochrona nierozerwalności małżeństwa i zbawienie wiernych (dobro dusz).

Papież, wskazując na te dwie naczelne zasady reformy procesu małżeńskiego, pragnie zwrócić uwagę, iż zasada nierozerwalności małżeństwa bywa we współczesnym świecie niezrozumiana, podważana i błędnie interpretowana. To powoduje, że stawiane są pytania o sensowność i praktyczny wymiar małżeństwa nierozerwalnego, a także błędne pojmowanie natury procesu o nieważność małżeństwa, o jaki się zwracają do sądów kościelnych. Ponieważ jednak jednym z podstawowych praw wiernych jest prawo do legalnego dochodzenia przysługujących im uprawnień na właściwym forum sądowym ${ }^{33}$, mogą oni i powinni dochodzić swoich uprawnień w tym względzie, szczególnie, kiedy kierują się sumieniem, niepozwalającym pozostawać na rozdrożu życia sakramentalnego, jak




też mają na względzie chęć zawarcia nowego małżeństwa kościelnego. Kościół winien im w tym pomóc, wskazując, że związek nierozerwalny tworzy zgoda stron, która jest przyczyną sprawczą każdego małżeństwa, o ile wyrażona jest pomiędzy osobami prawnie do tego zdolnymi. Wyrażona zgoda małżeńska nie powoduje zaistnienia małżeństwa, jeśli któryś z kontrahentów lub obydwoje są niezdolni prawnie według prawa naturalnego, pozytywnego czy kościelnego do jej wyrażenia ${ }^{34}$.

Już w części wstępnej dokumentu papież Franciszek zaznaczył, iż „w kwestii małżeństwa Kościół przez wieki, będąc coraz bardziej świadomy słów Chrystusa, rozumiał i przedstawiał w sposób dogłębny doktrynę o nierozerwalności świętego węzła małżeńskiego" ${ }^{35}$. Podkreślił też, że swoją decyzję podtrzymującą rozpoznawanie spraw nullitatis matrimonii na drodze sądowej, usprawiedliwia przede wszystkim „koniecznością zagwarantowania w najwyższym stopniu ochrony prawdy świętego węzła"36. Dlatego - jak to zaznaczono wcześniej powołany przez niego zespół ekspertów, z Dziekanem Roty Rzymskiej na czele, otrzymał zadanie przygotowania projektu reformy ,z pełnym poszanowaniem zasady nierozerwalności węzła małżeńskiego"37.

Zasada nierozerwalności małżeństwa, określona w kan. 1056 KPK, została zatem bardzo wyraźnie potwierdzona $\mathrm{w}$ analizowanym dokumencie i nadal czego nie zauważają świeckie środki masowego przekazu, komentujące nowe normy prawne papieża Franciszka zawarte w motu proprio - pozostaje zasada fundamentalną, określającą małżeństwo jako związek trwały, którego człowiek rozdzielić nie może i wskazująca, że związku małżeńskiego nie można zawierać na określony czas, lecz dozgonnie ${ }^{38}$.

Jednocześnie papież Franciszek zauważa, że nadszedł w Kościele czas, aby nie tylko prowadzić analizy i zgłębianie elementów istotnych dla ważności małżeństwa, roli i znaczenia wiary przy zawarciu małżeństwa sakramentalnego, szukania rozwiązań prawno-duszpasterskich dla osób rozwiedzionych, które zawarły ponowne związki cywilne, zmuszonych żyć na obrzeżach Kościoła, ale by działać i w ten sposób zapoczątkować dzieło sprawiedliwości i miłosierdzia, od dłuższego czasu oczekiwane, reformując praktykę duszpasterską i kanoniczną. Dlatego, szanując i wskazując na zasadę nierozerwalności małżeństwa jako fundamentu małżeństwa sakramentalnego, Papież zauważając, że miłość i miłosierdzie wymagają, aby Kościół jak matka stał się bliski swoim dzieciom, które czują się odłączone i uważają, że Kościół się od nich odwrócił, podejmuje dzieło

${ }^{34}$ Por. G. Leszczyński, Założenia ogólne motu proprio Mitis Iudex Dominus Iesus, w: Proces matżeński wedlug motu proprio Mitis Iudex Dominus Iesus, red. J. Krajczyński, Płock 2015, s. 25-27.

${ }^{35}$ Papież Franciszek, list apostolski motu proprio Mitis Iudex Dominus Iesus..., s. 7.

${ }^{36}$ Tamże, s. 11.

${ }^{37}$ Tamże, s. 9.

${ }^{38}$ Por. L. Leszczyński, Założenia ogólne motu proprio Mitis Iudex Dominus Iesus..., s. 25. 
reformy procesu małżeńskiego, stawiając w centrum ubogich, czyli rozwiedzionych, którzy zawarli ponowne związki ${ }^{39}$.

Drugą naczelną zasadą, na jaką wskazuje dokument papieski reformujący proces małżeński, jest zasada zbawienia dusz (dobro wiernych). Salus animarum pozostaje najwyższym celem oraz zasadniczą ideą i motywacją wprowadzonej reformy, która porządkuje i upraszcza przebieg procesu o orzeczenie nieważności małżeństwa, stając się szansą i nadzieją dla osób, które w swojej sytuacji małżeńskiej i rodzinnej odwracają się od struktur prawnych Kościoła na skutek fizycznego i moralnego oddalenia. Uproszczenie procedur procesowych, na co wskazuje papież Franciszek, nie ma na celu promowania nieważności małżeństwa, ale przyspieszenie prowadzenia procesów, jak również ich uproszczenia w taki sposób, aby serca wiernych, którzy oczekują na wyjaśnienie swojej sytuacji, nie były zbyt długo zniewolone przez „mroki wątpliwości z powodu opóźnień w wydawaniu wyroku" ${ }^{40}$.

\section{NIE DWA ZGODNE WYROKI ZA NIEWAŻNOŚCIĄ MAŁŻEŃSTWA, A JEDEN WYROK}

Do tej pory, zgodnie z kan. $1682 \S 1$ KPK, wyrok orzekający nieważność małżeństwa w pierwszej instancji, wraz z apelacjami, jeżeli takie były, i pozostałymi aktami sądowymi, należało przesłać z urzędu do trybunału apelacyjnego w ciagu dziesięciu dni od ogłoszenia wyroku. Dopiero po tym, gdy wyrok stwierdzający za pierwszym razem nieważność małżeństwa został potwierdzony przez trybunał apelacyjny dekretem lub drugim wyrokiem, ci, których małżeństwo zostało uznane za nieważne, mogli zawrzeć nowe małżeństwo zaraz po podaniu im do wiadomości dekretu lub wyroku. Jeżeli była dołączona do dekretu lub wyroku klauzula zakazująca zawarcie małżeństwa, należało zwrócić się do ordynariusza miejsca o jej zniesienie (zob. kan. $1684 \S 1$ KPK) $)^{41}$.

Motu proprio papieża Franciszka wprowadza tutaj zasadniczą zmianę. Otóż zasadą reformy jest to, że wyrok stwierdzający po raz pierwszy nieważność małżeństwa podlega wykonaniu i staje się prawomocny po zawitym terminie piętnastu dni użytecznych od wiadomości o ogłoszeniu wyroku, jeżeli strony, obrońca węzła małżeńskiego lub rzecznik sprawiedliwości nie wniosą apelacji od tego wyroku lub skargi o jego nieważnośćc ${ }^{2}$. W myśl zatem nowych norm, dla stwierdzenia nieważności małżeństwa nie będzie już konieczne zgodne orzeczenie dwóch instancji, czyli trybunału pierwszej i drugiej instancji. Sąd kościelny

${ }^{39}$ P.V. Pinto, Reforma procesu w sprawie orzekania nieważności matżeństwa..., s. 45.

${ }^{40}$ Papież Franciszek, list apostolski motu proprio Mitis Iudex Dominus Iesus..., s. 9-11.

${ }^{41}$ L. Leszczyński, Założenia ogólne motu proprio Mitis Iudex Dominus Iesus..., s. 27-28.

${ }^{42}$ Papież Franciszek, list apostolski motu proprio Mitis Iudex Dominus Iesus..., kan. 1679 i 1680 § 1, s. 25. Por. kan. 1630-1633 i 1619-1640 KPK. 
pierwszej instancji, po wydaniu wyroku stwierdzającego nieważność małżeństwa, nie będzie miał obowiązku z urzędu wysyłania akt sprawy do trybunału apelacyjnego drugiej instancji celem potwierdzenia lub też podważenia wydanej decyzji wyrokowej, poza oczywiście sytuacją kiedy apelację taką złożą strony procesowe, obrońca węzła małżeńskiego lub rzecznik sprawiedliwości - oni nadal mają prawo do apelacji. Ich apelacja będzie rozpatrywana przez trybunał apelacyjny drugiej instancji. Jeżeli jednak w sposób oczywisty będzie wynikało, że apelacja ma na celu jedynie działanie na zwłokę, trybunał apelacyjny winien potwierdzić swoim dekretem wyrok poprzedniej instancji ${ }^{43}$. Jeżeli apelacja została przyjęta, należy postępować odpowiednio jak w pierwszej instancji. Jeżeli zaś na stopniu apelacyjnym zgłoszony zostanie nowy tytuł nieważności małżeństwa, trybunał apelacyjny może go dopuścić i rozstrzygnąć, tak jak w pierwszej instancji4 ${ }^{4}$.

Powyższa zmiana, stanowiąca złagodzenie dotychczasowej dyscypliny dotyczącej konieczności dwóch wyroków zgodnych za nieważnością małżeństwa, rodzi wśród kanonistów pewne dyskusje i przytacza różne argumenty za sensownością zarówno jednego, jak i drugiego rozwiązania ${ }^{45}$. Zakładając jednak uczciwość i rzetelną pracę sędziów rozstrzygających sprawy małżeńskie oraz obrońcy węzła małżeńskiego, nie znajdzie się przekonywujących argumentów za wyższymi gwarancjami dotarcia do prawdy, jakie miałoby dawać postępowanie w trybunałach dwóch stopni, jeżeli założy się „moralną pewność osiąnniętą przez pierwszego sędziego zgodnie z przepisami prawa" ${ }^{46}$. Ponadto, należy podkreślić, że zachowana została jedna $\mathrm{z}$ fundamentalnych zasad procesu, a mianowicie zasada apelacji od wyroku. Wydaje się jednak, że nowa regulacja papieża Franciszka ma na celu przede wszystkim ekonomię procesową oraz czas trwania procesów, które, przechodząc przez dwie instancje, a w niektórych przypadkach i trzy, przeciągały się i trwały czasami latami. Sytuacja taka nie jest do pogodzenia z myślą Ojca Świętego Franciszka i jego pragnieniem, aby „serca wiernych, którzy oczekują na wyjaśnienie swojej sytuacji, nie były zbyt długo zniewolone przez mroki wątpliwości z powodu opóźnień w wydaniu wyroku”47.

\section{PROCES SKRÓCONY - NOWATORSKIE ZAŁOŻENIE REFORMY I PODKREŚLENIE POZYCJI SĄDOWNICZE] BISKUPA DIECEZJALNEGO}

Oprócz zmian i usprawnień poczynionych przez motu proprio Mitis Iudex Dominus Iesus papieża Franciszka w zwyczajnym procesie małżeńskim, została ustanowiona forma procesu skróconego (processus brevior), która stanowi kolej-

${ }^{43}$ Papież Franciszek, list apostolski motu proprio Mitis Iudex Dominus Iesus..., kan. $1680 \S$ 2, s. 25 .

${ }^{44}$ Tamże, kan. $1680 \S 3$ i 4, s. 25.

${ }^{45}$ Zob. G. Leszczyński, Założenia ogólne motu proprio Mitis Iudex Dominus Iesus..., s. 28-29.

${ }^{46}$ Papież Franciszek, list apostolski motu proprio Mitis Iudex Dominus Iesus..., s. 11.

${ }^{47}$ Tamże, s. 9-11. 
ne nowatorskie założenie reformy, stanowiące pewne wyzwanie dla trybunałów kościelnych. Proces skrócony - oprócz obecnie obowiązującego procesu opartego na dokumentach - nie będzie się odnosił do wszystkich wnoszonych do sądów kościelnych spraw, ale będzie go można zastosować w przypadkach, w których skarga o nieważność małżeństwa będzie poparta szczególnie oczywistymi, pewnymi przesłankami i argumentami. Aby postępowanie skrócone nie zagroziło zasadzie nierozerwalności małżeństwa, Papież postanowił, aby „w takim procesie sędzią był ustanowiony osobiście biskup diecezjalny, który mocą swego urzędu i zadania pasterskiego daje największą gwarancję katolickiej jedności z Piotrem w wierze i dyscyplinie" ${ }^{48}$. Jedynie zatem do biskupa diecezjalnego należy orzekanie w sprawach o nieważność małżeństwa w procesie skróconym, aby $\mathrm{w}$ ten sposób $\mathrm{z}$ większą mocą była chroniona zasada nierozerwalności małżeństwa.

Proces ten będzie mógł być prowadzony po spełnieniu, o czym będzie decydował wikariusz sądowy ${ }^{49}$, dwóch podstawowych warunków: jeżeli żądanie zostanie zgłoszone przez obydwoje małżonków lub jednego z nich za zgodą drugiego; jeżeli przytaczane będą okoliczności dotyczące faktów lub osób, poparte zeznaniami lub dokumentami, które nie wymagają przeprowadzenia dokładniejszego badania albo dochodzenia oraz w sposób oczywisty będą wskazywać na nieważność małżeństwa ${ }^{50}$. Konieczne zatem będą w tym przypadku jasne, pewne i oczywiste dowody nieważności małżeństwa, wtedy będzie możliwość zastosowania i przeprowadzenia procesu skróconego. Praktyka sądowa jednak wskazuje, że w niewielu tak naprawdę sprawach oczywistość faktów i dowodów, zwłaszcza w początkowym etapie postępowania, jest pewna i jednoznaczna. Oczywiście takie sprawy mogą się zdarzyć i wtedy jak najbardziej processus brevior będzie można prowadzić, ale tylko wtedy, kiedy zostanie spełniony drugi istotny warunek, a mianowicie zgodność obojga małżonków, co też w procesach małżeńskich nie jest takie proste.

Gdy jednak zostaną spełnione wspomniane dwa warunki, wikariusz sądowy w tym samym dekrecie, w którym określił formułę wątpliwości, po powołaniu sędziego instruktora i asesora, wzywa wszystkich, którzy powinni wziąć udział, na posiedzenie, które winno się odbyć w ciagu trzydziestu dni. Sędzia instruktor, o ile to możliwe, zbiera dowody podczas jednego posiedzenia i wyznacza termin piętnastu dni na przedstawienie uwag na korzyść węzła małżeńskiego oraz wniosków obrończych stron, jeżeli takie zgłaszaja ${ }^{51}$. Wyrok wydawany jest przez biskupa diecezjalnego, który po otrzymaniu akt sprawy, po konsultacji z sędzią

\footnotetext{
${ }^{48}$ Papież Franciszek, list apostolski motu proprio Mitis Iudex Dominus Iesus..., s.13; por. P.V. Pinto, Reforma procesu w sprawie orzekania nieważności malżeństwa..., s. 45-46.

${ }^{49}$ Papież Franciszek, list apostolski motu proprio Mitis Iudex Dominus Iesus..., kan. $1676 \S$ 2, s. 21.

${ }^{50}$ Por. tamże, kan. 1683, s. 27.

${ }^{51}$ Por. tamże, kan. 1685 i 1686, s. 29.
} 
instruktorem oraz asesorem, mając na względzie uwagi obrońcy węzła małżeńskiego i wnioski obrończe stron, gdy takie zgłoszono, winien osiagnąć moralną pewność co do nieważności małżeństwa. Pełny tekst wyroku wraz z uzasadnieniem winien zostać jak najszybciej notyfikowany stronom. Gdy zebrany materiał dowodowy nie przekona biskupa diecezjalnego do wydania wyroku za nieważnością małżeństwa, sprawa powraca do postępowania zwyczajnego ${ }^{52}$.

Możliwa też jest apelacja od orzeczenia biskupiego do metropolity lub do Roty Rzymskiej. Jeżeli wyrok został wydany przez metropolitę, apelacja przysługuje do najstarszego sufragana; od wyroku innego biskupa, który nie ma zwierzchnika niższego niż Biskup Rzymski, przysługuje apelacja do biskupa wybranego na stałe przez siebie ${ }^{53}$. Co ważne, jeżeli w sposób oczywisty wynika, że apelacja ma na celu jedynie działanie na zwłokę, metropolita lub biskup albo dziekan Roty Rzymskiej winni ją od razu odrzucić swoim dekretem. Jeżeli zaś apelacja została przyjęta, sprawę należy przekazać do procesu zwykłego na drugim stopniu ${ }^{54}$.

Wprowadzenie procesu skróconego, jako pewnego novum w procedurze sądowej, zasadniczo niczego poważniejszego nie zmieni w działaniach osób, które będa pragnęły wnieść do sądu kościelnego prośbę o orzeczenie nieważności małżeństwa. Jak wspomniano, wikariusz sądowy (oficjał), po zapoznaniu się ze skargą o nieważność małżeństwa, zdecyduje, czy sprawa nadaje się do skierowania jej na drogę procesu skróconego czy też nie. Decydować o tym będą argumenty i dowody przedstawione w sprawie przez strony procesowe. Jeżeli wikariusz sądowy uzna, że może być prowadzony proces skrócony, poinformuje o tym strony procesowe i wtedy proces będzie prowadzony przez biskupa diecezjalnego według formuły procesu skróconego. Ta wyłączna kompetencja biskupa diecezjalnego, wykluczająca możliwość udzielenia delegacji komukolwiek, stanowi istotny i nowatorski element procesowy. Potwierdzają to dobitnie słowa papieża Franciszka: „Należy zatem oczekiwać, że zarówno w dużych, jak i małych diecezjach, biskup osobiście da sygnał do odnowy struktur kościelnych oraz że nie pozostawi on całkowicie funkcji sądowniczej w sprawach małżeńskich urzędom kurialnym. Powinno się to odnosić szczególnie do procesu skróconego, który zostaje ustanowiony w celu rozpatrzenia spraw, w których istnieją najbardziej ewidentne przesłanki nieważności" ${ }^{55}$.

Powyższa, dość istotna i ważna zmiana sankcjonująca rozstrzyganie spraw małżeńskich przez jednego sędziego, jakim jest biskup diecezjalny w procesie skróconym, będzie wymagała właściwej współpracy i zaufania między biskupem

${ }^{52}$ Por. tamże, kan. 1687 § 1 i 2, s. 29.

${ }^{53}$ Por. tamże, kan. 1687 § 3, s. 29.

${ }^{54}$ Por. tamże, 1687 § 4, s. 29; Zob. M. Greszta-Telusiewicz, Processus brevior, w: Proces matżeński wedlug motu proprio Mitis Iudex Dominus Iesus, red. J. Krajczyński, Płock 2015, s. 80-85.

${ }^{55}$ Papież Franciszek, list apostolski motu proprio Mitis Iudex Dominus Iesus..., s. 11-13. 
a osobami przygotowującymi proces skrócony. Biskup diecezjalny występuje bowiem w tym procesie zasadniczo w wyrokowaniu, samo zaś przygotowanie sprawy, zbieranie dowodów leży w kompetencji instruktora, zaś wydanie opinii przedstawianej biskupowi należy do występującego $\mathrm{w}$ procesie asesora ${ }^{56}$. Stąd współpraca ta będzie stanowiła o jakości orzekanych spraw małżeńskich w procesie skróconym.

Kiedy mówimy o rozstrzyganiu spraw małżeńskich przez jednego sędziego, którym w przypadku processus brevior jest biskup diecezjalny, to normy papieża Franciszka wprowadzają jeszcze inną zmianę w procedurze procesowej o orzekaniu nieważności małżeństwa, a mianowicie możliwość prowadzenia procesu przez sędziego jednoosobowego, pod odpowiedzialnością biskupa diecezjalnego. Sędzia taki zawsze powinien być osobą duchowna, gwarantująca, że nie dojdzie w rozstrzyganiu sprawy małżeńskiej do jakiejkolwiek formy laksyzmu ${ }^{57}$. Sytuacja taka może zasadniczo dotyczyć jedynie diecezji, w których nie ma możliwości ukonstytuowania trybunałów kolegialnych. Zasadą bowiem pozostaje trybunał kolegialny, o czym wyraźnie mówi prawodawca w kan. 1673 3, zdefiniowanym w motu proprio, który wyraźnie stwierdza, że „sprawy o nieważność małżeństwa zastrzeżone są dla kolegium składającego się z trzech sędziów". Winien mu przewodniczyć sędzia, będący duchownym, pozostałymi zaś sędziami mogą być także świeccy.

Powyższe zmiany i wprowadzone nowe elementy procedury procesowej mają głęboki zamysł duszpasterski, aby, z jednej strony, zagwarantować i usprawnić właściwe funkcjonowanie wymiaru sprawiedliwości w Kościele, a z drugiej strony - wyjść naprzeciw potrzebie osób żyjących w związkach niesakramentalnych oraz ubiegających się o orzeczenie nieważności swego małżeństwa kościelnego poprzez uproszczenie procedury orzekania nieważności małżeństwa przy zagwarantowaniu ochrony jedności w wierze i w dyscyplinie dotyczącej małżeństwa. Wprowadzone zmiany nie mają na celu promowania nieważności małżeństwa, ale przyspieszenie prowadzonych przez sądy kościelne procesów, jak również ich uproszczenie w taki sposób, aby „serca wiernych, którzy oczekują na wyjaśnienie swojej sytuacji, nie były zbyt długo zniewolone przez mroki wattpliwości z powodu opóźnień w wydaniu wyroku"s8.

${ }^{56}$ Por. G. Leszczyński, Założenia ogólne motu proprio Mitis Iudex Dominus Iesus..., s. 30-31; por. M. Greszta-Telusiewicz, Processus brevior..., s. 79-81.

${ }^{57}$ Papież Franciszek, list apostolski motu proprio Mitis Iudex Dominus Iesus..., s. 11.

${ }^{58}$ Tamże, s. 10. 


\section{APELACJA NIE Z URZĘDU, ALE NA ŻYCZENIE STRON PROCESOWYCH, OBROŃCY WĘZŁA MAŁŻEŃSKIEGO I PROMOTORA SPRAWIEDLIWOŚCI}

Nowe przepisy papieża Franciszka, jak już sygnalizowano wcześniej, wprowadzają wystarczalność jednego wyroku za nieważnością małżeństwa. Kan. 1679 motu proprio Mitis Iudex Dominus Iesus - wskazuje, iż wyrok stwierdzający po raz pierwszy nieważność małżeństwa, po upływie terminów ustalonych w kan. 1630-1622 Kodeksu prawa kanonicznego (piętnaście dni użytecznych od wiadomości o ogłoszeniu wyroku), staje się wykonalny ${ }^{59}$. Nie oznacza to jednak, że w zreformowanym procesie małżeńskim traci na ważności i znaczeniu instytucja apelacji. Otóż pozostaje ona nadal fundamentalną i podstawową zasadą kanonicznego procesu małżeńskiego i stanowi nadal realizację przysługującego stronom prawa do obrony.

Według norm Kodeksu prawa kanonicznego z 1983 r., nikt, nawet obrońca węzła małżeńskiego, nie był zobowiązany do wniesienia apelacji od wyroku po raz pierwszy orzekającego nieważność małżeństwa. Jednakże taki wyrok, wydany przez pierwszą lub wyższą instancję, wraz z aktami sądowymi, musiał być przesłany $z$ urzędu do trybunału apelacyjnego celem ponownego rozpatrzenia sprawy. Jeżeli były apelacje czy to obrońcy węzła, czy strony pozwanej, przesyłano je wraz z wyrokiem i aktami do trybunału apelacyjnego ${ }^{60}$.

W świetle nowych przepisów motu proprio papieża Franciszka, nie ma apelacji z urzędu, a pozostaje apelacja na życzenie stron lub obrońcy węzła małżeńskiego, a także promotora sprawiedliwości, jeżeli występuje w procesie. Apelacja ta może dotyczyć zarówno wyroków pro nullitate, jak i wyroków pro validitate $^{61}$. Zatem strony procesowe, jeżeli czują się pokrzywdzone wyrokiem, obrońca węzła, jak i promotor sprawiedliwości, mają prawo wniesienia apelacji, zgodnie z kan. 1619-1640 Kodeksu prawa kanonicznego. Apelacja ta będzie rozpatrywana przez trybunał drugiej instancji. Nowością jest to, że jeżeli po wydaniu orzeczenia pozytywnego zgłaszana będzie apelacja, to może być ona odrzucona przez trybunał apelacyjny w przypadku ewidentnego braku argumentów, działania na zwłokę lub użycia apelacji instrumentalnie, aby zaszkodzić stronie przeciwnej ${ }^{62}$. Wtedy trybunał apelacyjny powinien potwierdzić swoim dekretem wyrok poprzedniej instancji. Gdyby w postępowaniu apelacyjnym zgłoszony został nowy tytuł nieważności małżeństwa, trybunał apelacyjny może go dopuścić i rozstrzygnać, podobnie jak to było w postępowaniu pierwszej instancji63.

\footnotetext{
${ }^{59}$ Por. tamże, kan. 1679, s. 25.

${ }^{60}$ Por. kan. $1682 \S 1$ KPK.

${ }^{61}$ Por. Papież Franciszek, list apostolski motu proprio Mitis Iudex Dominus Iesus..., kan. 1680

${ }^{62}$ Por. tamże, kan. 1680 § 2, s. 25.

${ }^{63}$ Tamże, kan. $1680 \S 3$ i 4, s. 25.
} $\S 1$, s. 25. 
Z realizacją prawa do apelacji wiąże się ściśle kwestia opublikowania wyroku zgodnie z przepisami prawa. Jest to konieczne i niezbędne do zagwarantowania stronom możliwości poznania motywacji wyroku, a w konsekwencji - jeżeli strony czują się pokrzywdzone wyrokiem - możliwości złożenia stosownej, przewidzianej w konkretnym terminie, apelacji ${ }^{64}$. Wskazuje na to jednoznacznie art. 257 § 1 Instrukcji procesowej Dignitas connubii, który stwierdza, że nawet wówczas, gdy część wyroku już podana została do wiadomości stron, wyrok nabiera mocy prawnej dopiero wraz z jego publikacja ${ }^{65}$. Bez poznania przez strony pełnego brzmienia wyroku dostarczonego (opublikowanego) stronom, trudno mówić o znajomości przez nich motywacji i uzasadnienia wyroku. Kan. $1630 \S 1$ Kodeksu prawa kanonicznego wskazuje również na termin złożenia apelacji. Liczy się on - jak wspomniano - od dnia otrzymania wiadomości o ogłoszeniu wyroku, co w świetle nowych przepisów jest niezwykle ważne ${ }^{66}$. Dla zagwarantowania stronom procesowym prawa do obrony, między innymi tym prawem jest apelacja, sędzia, ogłaszając wyrok, jest zobowiązany wskazać konkretne środki, przy pomocy których wyrok może być podważony ${ }^{67}$.

\section{ZAKOŃCZENIE}

Przybliżone i omówione główne założenia reformy procesu w sprawie orzekania nieważności małżeństwa, zawarte w innowacyjnym motu proprio Mitis Iudex Dominus Iesus papieża Franciszka, wpisują się w długi ciąg ewolucji kościelnych norm prawnych, regulujących instytucję kanonicznego procesu o nieważność małżeństwa. Stanowią jednocześnie wyraz troski najwyższego ustawodawcy kościelnego o dobro duchowe małżonków rozwiedzionych i trwających w nowych związkach, którzy pragną uregulować swój status cywilny na forum kościelnym, a tym samym poznać prawdę o swoim małżeństwie kościelnym. To oni - w myśl słów Papieża - jako ubodzy, czyli rozwiedzeni, zostali postawieni w centrum reformy procesu o orzekanie nieważności małżeństwa. Papież, wydając ten dokument, a tym samym promulgując nowe kanoniczne prawo procesowe o nieważność małżeństwa, kieruje się zasadą salus animarum suprema lex (por. kan. 1752), która zawsze towarzyszyła Kościołowi i która powoduje, że „wszystkie instytucje Kościoła dążą do przekazywania łaski Bożej oraz sprzyjają

${ }^{64}$ Kan. $1612 \S 3$ KPK; or. G. Leszczyński, Założenia ogólne motu proprio Mitis Iudex Dominus Iesus..., s. 33.

${ }^{65}$ Por. Pontificium Consilium de Legum Textibus, Instructio servanda a tribunalibus dioecesanis et interdioecesanis in pertractandis causis nullitatis matrimonii "Dignitas connubii”, Libreria Editrice Vaticana 2005, art. 257 § 1.

${ }^{66}$ Zob. kan. 1630 § 1 KPK.

${ }^{67}$ Papież Franciszek, list apostolski motu proprio Mitis Iudex Dominus Iesus..., s. 15. 
dobru wiernych"68. Tym samym założenia reformy kanonicznego procesu małżeńskiego mają na względzie przede wszystkim zbawienie dusz.

Ta najważniejsza i fundamentalna zasada prawa kościelnego znajduje realizację $\mathrm{w}$ konkretnych przepisach zreformowanego procesu, w którym wierny i jego duchowe dobro zdają się być wartościami nadrzędnymi. W tym kierunku idzie reforma i nowe regulacje papieża Franciszka, aby uprościć procedury sądowe, a poprzez to przyspieszyć prowadzenie procesów kościelnych o nieważność małżeństwa i w ten sposób służyć wiernym rozwiedzionym, żyjącym w nowych związkach. Zmiany te mają też ułatwić kontakt wiernych z trybunałami kościelnymi, co w konsekwencji ma się przyczynić do rozwiązania wątpliwości sumienia, które utrudniają życie wielu ludziom. Nadto, mają im dać okazję „,skorzystania z posługi i miłosierdzia, z jaką wychodzi do nich Kościół, dając możliwość zawarcia nowego małżeństwa kanonicznego, jeżeli okaże się to możliwe" ${ }^{69}$. Papież jednocześnie podkreśla, że we wprowadzonych zmianach nie chodzi o naruszenie zasady nierozerwalności małżeństwa, ale, przeciwnie, o jej zestawienie z konkretnymi przypadkami małżeństw zawieranych w sposób nieważny. Prowadzenie procesu o nieważność małżeństwa ma się dokonywać z całkowitym uwzględnieniem natury małżeństwa, którym jest poszanowanie prawdy. Dążenie do niej gwarantuje sprawiedliwy wyrok, który staje się realizacją prawa miłości.

Nowe przepisy, aby przyniosły oczekiwane rezultaty i spełniły zakładane cele oraz zostały wprowadzone i zastosowane w prawdzie i sprawiedliwości, wymagają całościowego, krytycznego „zamyślenia” nad dotychczasowym funkcjonowaniem sądownictwa Kościoła oraz otwarcia na novum, jakie przynoszą. Ponadto - wymagają zgodnego z prawem ich stosowania, rzetelności, a czasami zmiany mentalności w podejściu do spraw i problemów sądownictwa kościelnego pracowników trybunałów, a przede wszystkim wielkiej odpowiedzialności biskupów diecezjalnych. Tylko wtedy mogą one stać się wielką pomocą w rozwiązywaniu trudnych, bolesnych i powikłanych spraw małżeńskich wiernych. W ten sposób Kościół będzie realizował swoją zbawczą misję i zamysł duszpasterski nad nową ewangelizacją, także poprzez instrumenty prawne, w czym uwidacznia się ostateczny cel i uzasadnienie prawa kanonicznego.

\section{SUMMARY}

The reform of a process on the recognition of nullity of marriage, contained in the motu proprio Mitis Iudex Dominus Iesus of Pope Francis, clearly fits the new evangelization and it is, in relation to marriage and family, an important legal and pastoral element. Through the reform of

\footnotetext{
${ }^{68}$ Tamże, s. 7.

${ }^{69}$ Tamże, s. 9; por. P.V. Pinto, Reforma procesu w sprawie orzekania nieważności matżeństwa..., s. 44
} 
canon marriage process the new evangelization gets even more power and a new spirit. It is also an expression of concern of the supreme legislator in the Church for spiritual good of divorced and remarried spouses who wish to regularize their marital status in the Church, and thus learn the truth about their marriage. They - as poor, or divorced - were put in the center of the reform of the process on the recognition of nullity of marriage. The Pope promulgating the new canonical procedural law relating to nullity of marriage follows the principle salus animarum suprema lex (can. 1572), which has always accompanied the Church and mainly into consideration salvation of souls. This important and fundamental principle of church law is implemented in specific regulations of the reformed process in which the faithful and their spiritual well-being seem to be paramount. The reform and new regulations of the Pope Francis go in this direction to simplify judicial procedures and thus speed up the processes on nullity of marriage, in order to serve the divorced and the remarried. The changes are also designed to facilitate contact between the faithful and church tribunals, which in turn is expected to contribute to solve a problem of conscience which makes life difficult for many people. As the Pope emphasizes, the changes introduced do not breach the principle of the indissolubility of marriage. On the contrary, this principle is juxtaposed with specific cases of invalid marriages. Conducting the process on nullity of marriage should take place in full respect of the nature of marriage, which is to respect the truth. The quest for it guarantees fair judgment, which becomes the realization of the law of love. The new rules, to bring the expected results, to meet its objectives, and to be introduced and applied in truth and justice, require a comprehensive, critical „consideratin” on the current functioning of the Church judiciary and openness to novelty they bring. Moreover, they need freedom of heart and mind of bishops, in a sign of collegiality - not in principle, but real, as well as new legal and pastoral structures (legal and family clinics), and also a change of mentality in the approach to the issues and problems of ecclesiastical judiciary system of diocesan bishops and employees of the Church judiciary.

\section{Keywords}

the process of nullity of marriage, Pope Francis, motu proprio Mitis Iudex Dominus Iesus, reform of the process of marriage, nullity of marriage

\section{BIBLIOGRAFIA}

\section{Źródła}

Benedictus XIV, Constitutio Dei miseratione (03.11.1741), w: Codicis Iuris Canonici Fontes, t. I, ed. P. Gasparri, Romae 1923, s. 695-701.

Canones et Decreta Concilii Tridentini ex editione Romana A. MDCCCXXXIV. Repetiti. Accedunt S. Congr. Card. Conc. Trid. Interpretum Declarationes ac Resolutiones ex ipso resolutionum thesuaro Bullario Romano et Benedicti XIV. S.P. Operibus et Constitutiones Pontificiae Recentiores ad jus commune spectantes e bullario Romano selectae. Assumpto Socio Friderico Schulte J.U.D. Guestphalo edidit Aemilius Ludovicus Richter J.U.D. Et in Lit. Univ. Berol. Prof. Publ. Ord., Lipsiae 1853.

Codex Iuris Canonici. Auctoritate Ioannis Pauli pp. II promulgatus. Kodeks Prawa kanonicznego. Przekład polski zatwierdzony przez Konferencję Episkopatu, Poznań: Pallottinum 1984.

Codex Iuris Canonici. Pii X Pontificis Maximi iussu digestus. Benedicti Papae XV auctoritate promulgatus, red. P. Gasparri, Romae 1934. 
Decretalium Collectiones [...] editio Lipsiensis secunda post Aemilii Ludouici Richteri curas ad librorum manu scriptorium et editionis Romae fidem recognovit et adnotatione critica instruxit Aemilius Friedberg, Ex Officina Bernhardi Tauchnitz, Lipsiae MDCCCLXXXI.

Komentarz do Instrukcji procesowej „Dignitas connubii”, red. T. Rozkrut, Sandomierz 2007.

Papież Franciszek, bulla ustanawiająca nadzwyczajny Jubileusz Miłosierdzia Misericordiae vultus (11.04.2015), „Miesięcznik Diecezji Włocławskiej - Kronika” 98(2015), nr 5, s. 489-508.

Papież Franciszek, list apostolski motu proprio Mitis Iudex Dominus Iesus, reformujący kanony Kodeksu prawa kanonicznego dotyczące spraw o orzeczenie nieważności małżeństwa; List apostolski Mitis et misericors Iesus, reformujący kanony Kodeksu kanonów kościołów wschodnich dotyczące spraw o orzeczenie nieważności małżeństwa (tekst łacińsko-polski), Tarnów 2015.

Paulus VI, Constitutio apostolica Regimini Ecclesiae universae (15.08.1967), AAS 59(1967), s. 885-928.

Paulus VI, Litterae apostolacie motu proprio datae quibus normae quaedam statuuntur ad processus matrimoniales expeditus absolvendos (28.03.1971), AAS 63(1971), s. 441-446.

Pius X, Constitutio apostolica Sapienti Consilio (29.06.1908), AAS 1(1909), s. 9-135.

Pontificium Concilium de Legum Textibus, Instructio servanda a tribunalibus dioecesanis et interdioecesanis in pertractandis causis nullitatis matrimonii "Dignitas connubii”, Libreria Editrice Vaticana 2005.

S. Congregatio pro Sacramentis, Instructio servanda a tribunalibus dioecesanis in pertractandis causis de nullitate matrimoniorum (15.08.1936), AAS 28(1936), s. 313-362.

\section{Literatura}

Góralski W., Uprawnienia udzielone trybunałom kościelnym Belgii oraz Anglii $i$ Walii w zakresie procesu matżeńskiego, „Prawo Kanoniczne” 17(1974), nr 3-4, s. 107-115.

Góralski W., Wprowadzenie do motu proprio „Mitis Iudex Dominus Iesus”, w: Proces małżeński wedtug motu proprio Mitis Iudex Dominus Jesus, red. J. Krajczyński, Płock 2015, s. 7-21.

Greszta-Telusiewicz M., Processus brevior, w: Proces matzeński wedtug motu proprio Mitis Iudex Dominus Iesus, red. J. Krajczyński, Płock 2015, s. 75-92.

Leszczyński G., Założenia ogólne motu proprio Mitis Iudex Dominus Iesus, w: Proces małżeński wedtug motu proprio Mitis Iudex Dominus Iesus, red. J. Krajczyński, Płock 2015, s. 23-36.

Pawluk T., Prawo kanoniczne wedtug Kodeksu Jana Pawła II, t. IV: Dobra doczesne Kościoła, Sankcje w Kościele, Procesy, Olsztyn 1990. 
Pawluk T., Reforma kanonicznego procesu malżeńskiego w świetle motu proprio „Causas matrimoniales”, „Prawo Kanoniczne” 16(1973), nr 3-4, s. 242-254.

Pieronek T., Normy postępowania w sprawach malżeńskich wydane przez Stolice Apostolskq dla diecezji Stanów Zjednoczonych, „Prawo Kanoniczne” 16(1973), nr 1-2, s. $177-204$.

Pinto P.V., Reforma procesu w sprawie orzekania nieważności matżeństwa, „L'Osservatore Romano" (ed. polska), 36(2015), nr 11, s. 44-46.

Przybyła A., Prawo kanoniczne w świetle obrad Synodu Biskupów, „Ateneum Kapłańskie” 71(1968), s. 157-168.

Sobański R., Między rygoryzmem a laksyzmem. Kanoniczny proces o nieważność matżeństwa na tle kondycji matżeństw sakramentalnych w Polsce, „Prawo Kanoniczne” 53(2010), nr 3-4, s. 161-169.

Janusz Gręźlikowski - ur. 28.03.1954 r. w Toruniu, kapłan diecezji włocławskiej, dr hab. nauk prawnych w zakresie prawa kanonicznego; profesor UKSW w Warszawie, kierownik Katedry Historii Prawa Kanonicznego na Wydziale Prawa Kanonicznego UKSW; oficjał Sądu Biskupiego we Włocławku; wykładowca prawa kanonicznego w Wyższym Seminarium Duchownym we Włocławku i Wyższym Seminarium Duchownym Księży Misjonarzy Świętej Rodziny w Kazimierzu Biskupim. Autor ok. 400 prac naukowych i popularnonaukowych, w tym pięciu książek. 